\title{
Sistem Monitoring dan Kontrol Berbasis Internet of Things untuk Penghematan Listrik pada Food and Beverage
}

\author{
Ali Khumaidi \\ Program Studi Teknik Informatika, Universitas Krisnadwipayana, Jakarta, Indonesia \\ e-mail: alikhumaidi@unkris.ac.id
}

\begin{abstract}
Abstrak
Departemen Food and Beverage (F\&B) menjadi salah satu sumber penghasilan dari perusahaan. F\&B menggunakan berbagai peralatan dan mesin dengan daya yang cukup besar untuk mendukung operasional, jika pemakaiannya tidak dikendalikan maka menyebabakan biaya listrik yang tinggi. Penggunaan peralatan dan mesin harus rutin dikontrol, jika kondisi peralatan tidak normal dapat mengakibatkan pemakaian listrik menjadi berlebih hingga kerusakan. Dalam mengendalikan pemakaian listrik dibutuhkan sebuah sistem yang dapat memonitor dan mengendalikan penggunaan energi listrik. Beberapa publikasi sebelumnya sudah ada yang meneliti terkait monitoring penggunaan listrik berbasis internet of things namun belum ada yang meneliti terkait monitoring dan kontrol peralatan dan mesin pada F\&B. Pada penelitian ini untuk mengontrol dan mengendalikan peralatan digunakan arduino mega2560, ethernet shield, sensor suhu, sensor magnet, sensor arus ACS712, fusethermo, dan modul wifi. Hasil pengujian prototipe bahwa sistem yang dibangun bekerja dengan baik dan mampu memonitoring penggunaan energi listrik serta dapat mengendalikan peralatan dari jarak jauh serta pengontrolan segala bentuk kerusakan yang disebabkan kelalaian perawatan terhadap peralatan dapat diminimalisir dengan adanya sensor-sensor yang terpasang pada tiap alat.
\end{abstract}

Kata kunci: Monitoring, Kontrol, IOT, Listrik, Food and Beverage

\begin{abstract}
The Department of Food and Beverage (F\&B) is a source of income from the company. However, the expenditure of electrical energy on the use of equipment or machines with large electrical power becomes high if it is not controlled. The use of such equipment must also be routinely controlled, if equipment conditions are not normal it can result in excess electricity usage until the damage will result in F\&B operations. To overcome this we need a system that can monitor and control the use of electrical energy that is not right. In some previous publications there have been researches related to monitoring the use of electricity based on internet of things, but no one has examined the monitoring and control of equipment or machinery in F\&B. In this research, to control and control the equipment using Arduino Mega2560, Ethernet Shield, Temperature Sensor, Magnetic Sensor, ACS712 Current Sensor, Fusethermo, and WiFi Module. Based on the results of the prototype testing system that the system is built to work well that can monitor the use of electrical energy and can control equipment remotely and control all forms of damage caused by negligence maintenance of the equipment can be minimized by the sensors installed on each tool.
\end{abstract}

Keywords : Monitoring, Control, IoT, Electricity, Food and Beverage

\section{Pendahuluan}

Departemen Food and Beverage (F\&B) adalah unit yang memiliki fungsi dalam pengolahan dan penyajian makanan atau minuman kepada tamu hotel, baik untuk pelayanan coffee shop (restoran), banquet (resepsi atau pertemuan), kamar tamu, katering, karyawan, dan lainnya [1]. Istilah F\&B tidak hanya digunakan untuk perhotelan, penyedia jasa penjualan makanan dan minuman seperti restoran atau kafe sering kali memakainya. Departemen F\&B merupakan salah satu departemen yang sangat menguntungkan bagi perusahaan. Berdasarkan hasil observasi dan wawancara terdapat sisi yang cukup besar beban biaya yang 
dikeluarkan, diantaranya adalah pemakaian energi listrik yang boros. Area dapur terdapat sejumlah peralatan mesin dengan konsumsi daya watt listrik yang relatif besar, seperti unit walk in chiller (ruangan pendingin/pembeku makanan, sayuran dan daging), blower wheel, exhaust fan, mesin cuci piring, water heater, dan penggunaan lampu penerangan yang tidak teratur pemakaiannya sesuai dengan kondisi dan jam kerja.

Penggunaan peralatan pada departemen F\&B sudah merupakan keharusan dan tidak boleh sampai tidak berfungsi atau rusak. Tidak berfungsinya peralatan dapat menyebabkan terhambatnya operasional dan pelayanan. Tidak semua departemen F\&B memiliki bagian engineering tersendiri, dan jika memiliki engineering maka setiap terjadi permasalahaan pada peralatan dapat segera ditangani serta adanya pengecekan secara rutin untuk memastikan peralatan dapat berfungsi secara normal. Kegiatan pengecekan bertujuan supaya ketika terjadi kondisi tidak normal segera ada penanganan. Jika dibiarkan dapat berdampak pada kerusakan peralatan atau mesin sehingga mengakibatkan pemborosan energi listrik.

Hasil kajian dari beberapa penelitian sebelumnya telah berhasil memanfaatan Internet of Things (IOT) untuk monitoring penggunaan listrik pada gedung [2][3][4][5]. Desain manajemen gedung dengan memanfaatkan arduino [6][7] dan smart grid power system [8] juga mampu mengurangi penggunan energi listrik. Publikasi hasil terkait deteksi kerusakan alat salah satunya terkait kerusakan air conditioner menggunakan arduino [9][10].

Permasalahan penghematan listrik pada F\&B dapat memanfaatkan IOT sebagai solusi untuk memonitor dan mengontrol penggunaan energi listrik serta untuk mendeteksi adanya ketidaknormalan peralatan dan mesin. Sistem monitoring dan kontrol dapat membantu bagian engineering dalam aktivitas kerja dan mengetahui peralatan dengan penggunaan energi melebihi batas normal. Tujuan penelitian untuk merancang dan membangun prototipe yang dapat memonitoring dan mengontrol penggunaan listrik serta mendeteksi adanya kerusakan pada peralatan sehingga pemborosan penggunaan listrik dapat dikendalikan. Penelitian ini diharapkan memberi manfaat dapat mengurangi biaya pengeluaran untuk listrik, mengetahui peralatan yang tidak normal sehingga dapat mengakibatkan kerusakan atau kerugian dalam operasional.

\section{Metodologi Penelitian}

Penelitian ini menggunaan metode pelaksanaan penelitian yang dapat dilihat pada Gambar 1. Tahap pertama adalah identifikasi masalah dengan melakukan observasi dan wawancara dengan 2 departemen F\&B, diperoleh beberapa peralatan listrik selain lampu yaitu peralatan seperti pada Gambar 2. Permasalahan yang sering terjadi yaitu sering lupa mematikan peralatan listrik ketika tidak operasional dan tidak rutin dalam mengontrol peralatan sehingga dapat menyebabkan kerusakan mendadak dan boros listrik. Tahap kedua yaitu melakukan kajian literatur melalui jurnal dan e-book yang berkaitan monitoring dan kontrol penggunaan listrik dengan IOT serta mikrokontroller, arduino, thingspeak, sensor suhu, sensor magnet, sensor arus, dan sensor deteksi.

Tahap ketiga yaitu perancangan sistem, dengan hasil desain dapat dilihat pada Gambar 4 dan perancangan topologi serta komunikasi antar perangkat seperti pada Gambar 5. Hasil rancangan sistem diperoleh hubungan antar perangkat, kebutuhan sensor, komponen, hardware dan software. Tahap keempat adalah desain Printed Circuit Board (PCB) untuk memastikan semua perangkat dapat terkoneksi dan terkontrol. Tahap kelima yaitu implementasi hardware dan software dilanjutkan dengan pengujian menggunakan black box testing. Pengujian pertama adalah pengujian hardware, jika ada komponen atau sensor tidak berfungsi dapat diganti. Pengujian software untuk memastikan fungsi monitoring dan pengendalian pada perangkat atau mesin F\&B melalui aplikasi web dan android. 

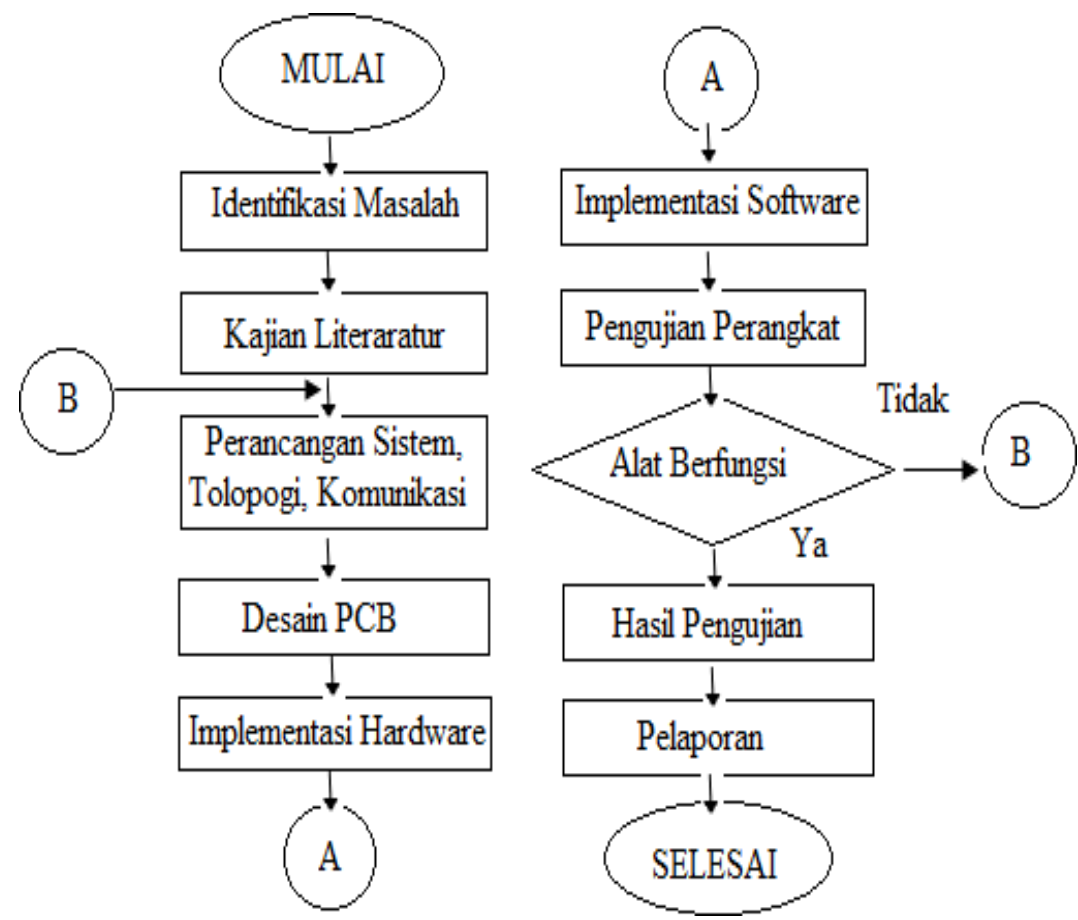

Gambar 1. Flowchart pembuatan sistem

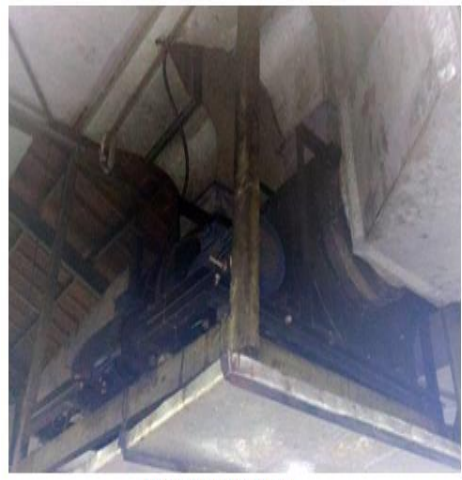

Unit Blower Wheel

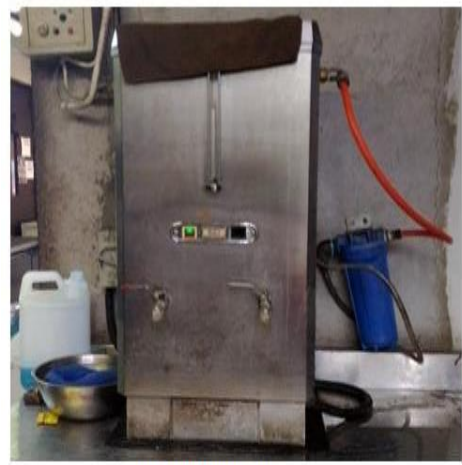

Unit Water Heater

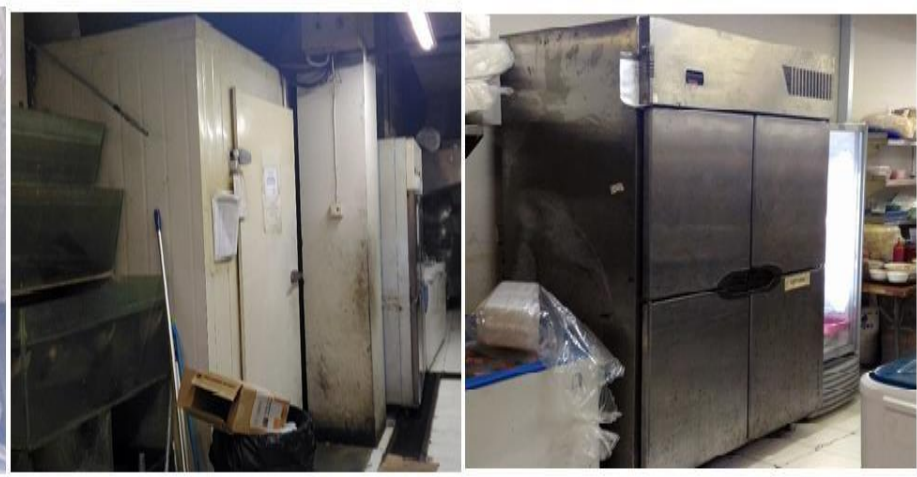

UnitWaklin Chiller

Freezer 4 Pintu

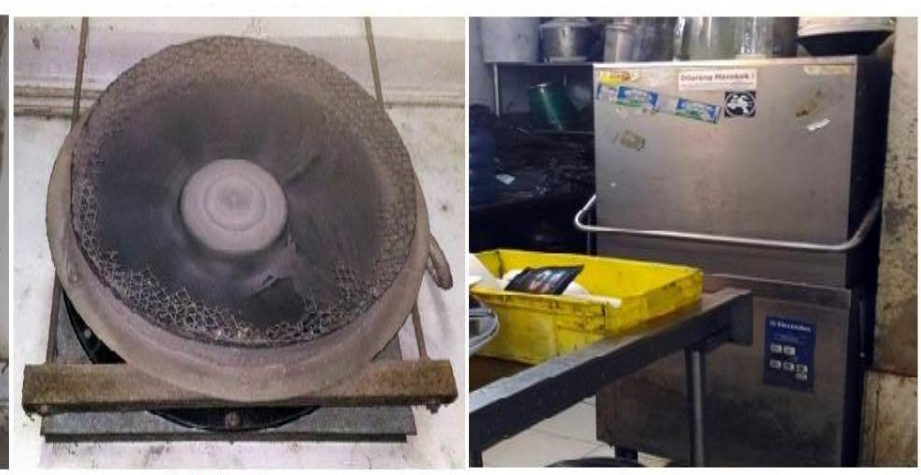

Unit Exhaust Fan
Mesin Pencucic Pinng

Gambar 2. Peralatan pada F\&B 


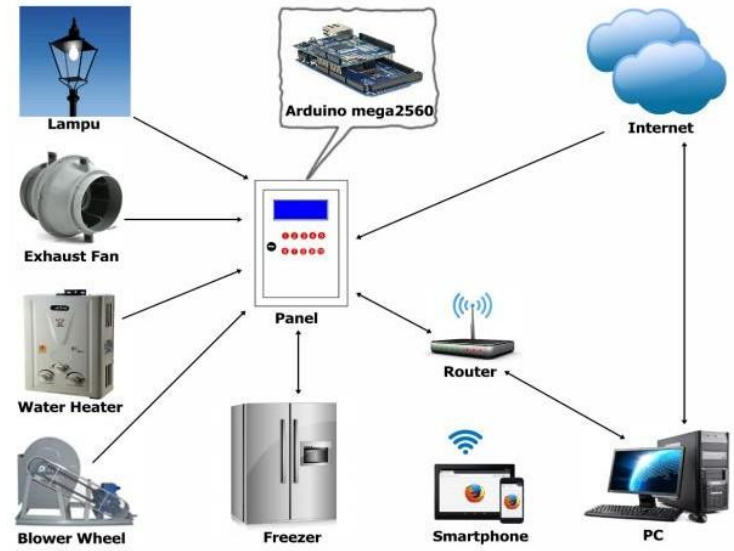

Gambar 3. Rancangan sistem

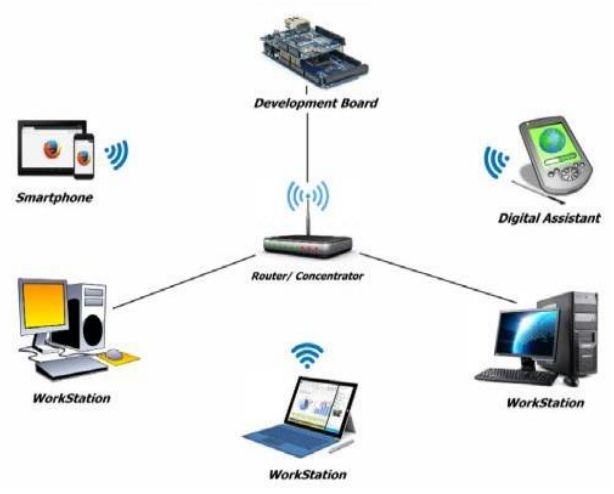

Gambar 4. Rancangan topologi

\section{Hasil dan Pembahasan}

Hasil desain PCB tampak seperti pada Gambar 5. Tabel 1 adalah kebutuhan perangkat dalam implementasi yang terbagi kategori hardware dan software. Implementasi sistem monitoring dan kontrol berbasis IOT dibagi dua bagian yaitu pengembangan hardware atau development board dan pengembangan software. Alur kerja development board dapat dilihat pada Gambar 6 dan langkah implementasi development board meliputi:

1. Perakitan PCB dan resistor, bertujuan untuk memberikan kestabilan pin (kaki IC) yang dijadikan sensor maupun button

2. Perakitan saklar (switch), dijadikan tombol untuk menyalakan lampu dan unit peralatan yang ditempatkan pada box panel perangkat

3. Merangkai ethernet shield dengan arduino mega2560

4. Merangkai LCD 20x4 karakter yang terhubung ke arduino mega2560

5. Merangkai modul relay yang terhubung dengan arduino mega2560

6. Merangkai sensor yang terhubung dengan arduino mega2560

7. Rangkaian keseluruhan development board

Hasil implementasi development board ditempatkan pada box panel yang dapat dilihat pada Gambar 7 dan rangkaian keseluruhan development board terlihat pada Gambar 8.

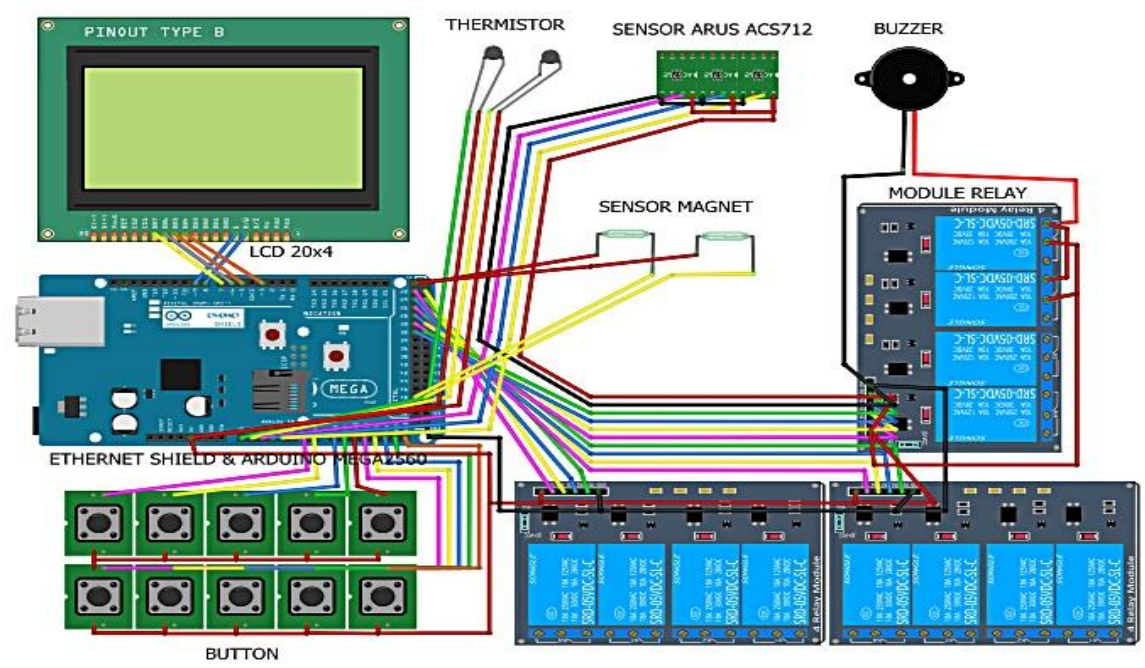

Gambar 5. Desain PCB perangkat development board 


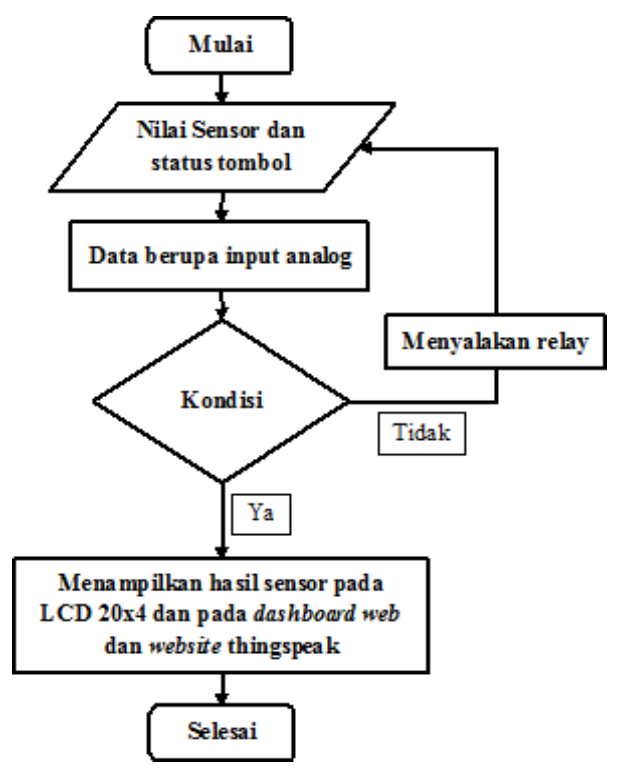

Gambar 6. Flowchart development board

Tabel 1. Kebutuhan hardware dan software

\begin{tabular}{lll}
\hline \multicolumn{1}{c}{ Hardware } & \multicolumn{1}{c}{ Fungsi } \\
\hline 1. & Router Mikrotik RB951-2HnD & Konfigurasi jaringan \\
2. & Arduino Mega2560 & Perangkat pengendali \\
3. & Ethernet shield & Koneksi arduino dengan internet \\
4. Sensor Suhu (Thermistor) 10k & Deteksi suhu \\
5. Sensor Magnet & Saklar aliran listrik \\
6. Sensor Arus ACS712 30A & Deteksi arus listrik \\
7. Modul relay & switch On/Off \\
8. LCD 20X4 Karakter & Penampil data \\
9. Modul wifi wemos D1 & Penghubung ke Wifi \\
\hline \multicolumn{1}{c}{ Software } & \multicolumn{1}{c}{ Fungsi } \\
\hline 1. & Arduino IDE & Memprogram Arduino \\
2. Sublime Text 3 & Menulis kode program \\
3. Web Browser & Membuka aplikasi web \\
4. App Inventor & Memprogram aplikasi android \\
5. HTML, JavaScript dan C++ & Memprogram \\
6. Winbox & Konfigurasi mikrotik \\
7. ThingSpeak & Aplikasi upload data \\
\hline
\end{tabular}

Langkah-langkah pada implementasi software yaitu sebagai berikut:

1. Inslatasi Arduino IDE, Sublime Text 3, Web browser Mozilla, Winbox, App Inventor dan koneksi ThingSpeak

2. Konfigurasi Router OS Mikrotik

3. Pemberian logika melalui kode program (source code) pada perangkat keras

4. Membuat tampilan user interface agar mudah dipahami serta mudah digunakan dalam hal pengoperasiannya 


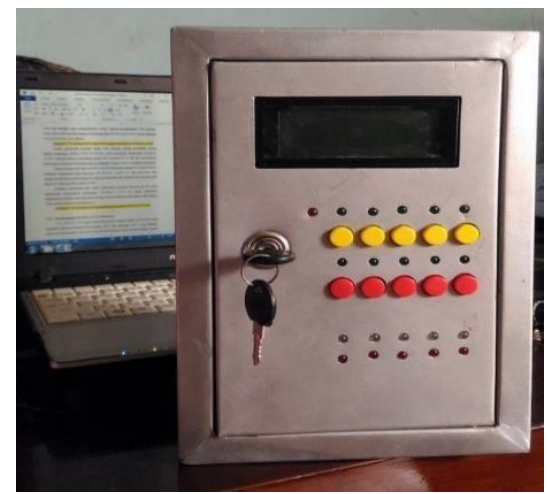

Gambar 7. Desain box panel development board

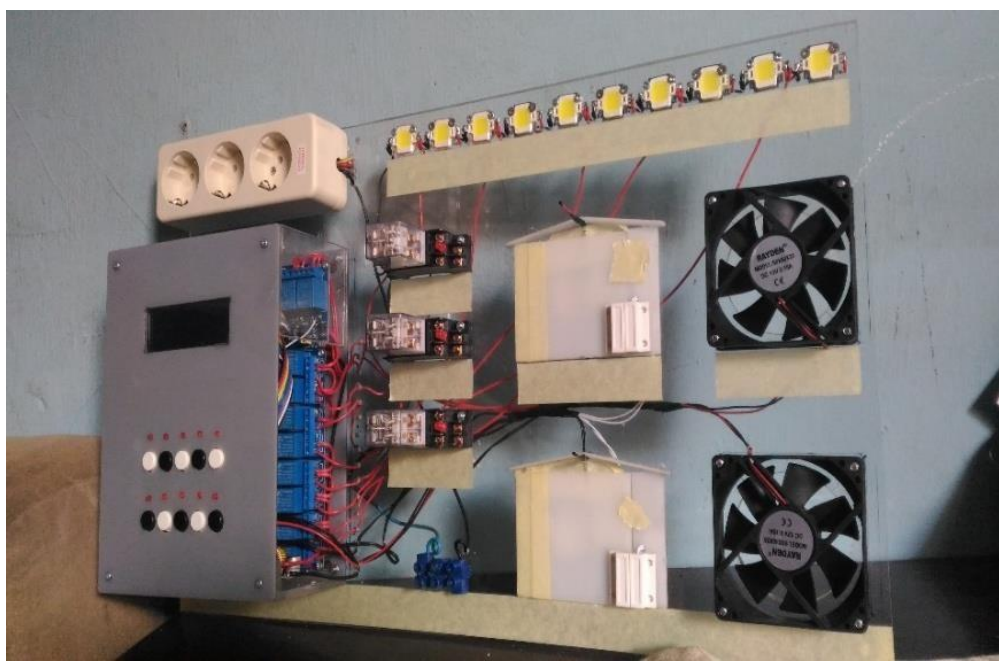

Gambar 8. Rangkaian keseluruhan development board

User Interface dari sistem tersedia dalam bentuk dashboard yaitu tampilan informasi berupa keterangan status dari tiap-tiap button yang terdapat pada panel perangkat, dan juga tampilan keterangan suhu ruangan dalam bentuk visual gauge-meter yang disertai tampilan dalam bentuk angka-angka, keterangan notifikasi status, serta keterangan status koneksi sensor suhu yang digunakan. Tampilan didesain dan dikembangkan berbasis desktop dan android. Hasil user interface yang dibangun seperti pada Gambar 9 dan Gambar 10.

Pengujian dilakukan terhadap keseluruhan sistem yang dibangun dengan membagi menjadi 4 pengujian sebagai berikut:

1. Pengujian development board

Pengujian development board untuk melihat hasil pembacaan signal sensor, pemisahan signal noise, dan fungsi tombol dengan membandingkan hasil pembacaan data dari sensor dengan alat thermometer digital merek KRISBOW KY-03 untuk suhu dan alat amperemeter KYORITSU 2007A untuk arus.

2. Pengujian kirim dan terima data pada development board

Pengujian pengiriman data dari development board untuk mengetahui hasil pembacaan data dari modul development yang dijadikan server.

3. Pengujian dashboard

Pengujian dashboard meliputi tampilan graphical user interface (GUI), push data terbaru, dan update tampilan. Pengujian dashboard untuk mengetahui sejauh mana fungsi dari aplikasi yang telah dibuat, mulai dari pembacaan sensor suhu, pembacaan sensor arus listrik, fungsi sensor magnet, termasuk pengendalian saklar lampu dan saklar untuk peralatan yang terpasang. Pengujian dilakukan dengan cara mengakses IP address dengan jarak +- 100 meter (jangkauan wireless). 
4. Pengujian IOT

Pengujian IOT akan menampilkan hasil pembacaan sensor pada platform analisis IOT yaitu ThingSpeak [11][12]. Tujuannya untuk mengetahui sejauh mana kemampuan sistem yang dibuat untuk bisa meng-upload data yang dihasilkan sensor ke website ThingSpeak.

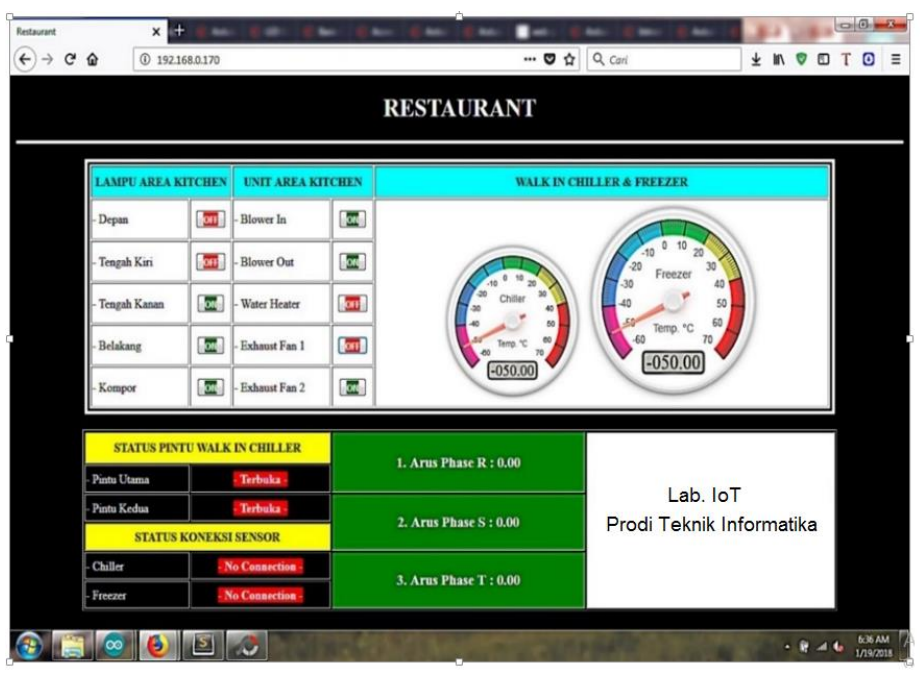

Gambar 9. Desktop User Interface (UI)

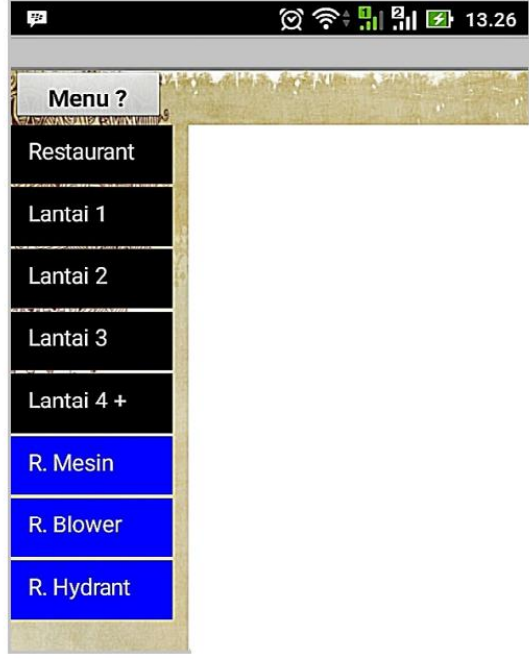

Gambar 10. Android UI

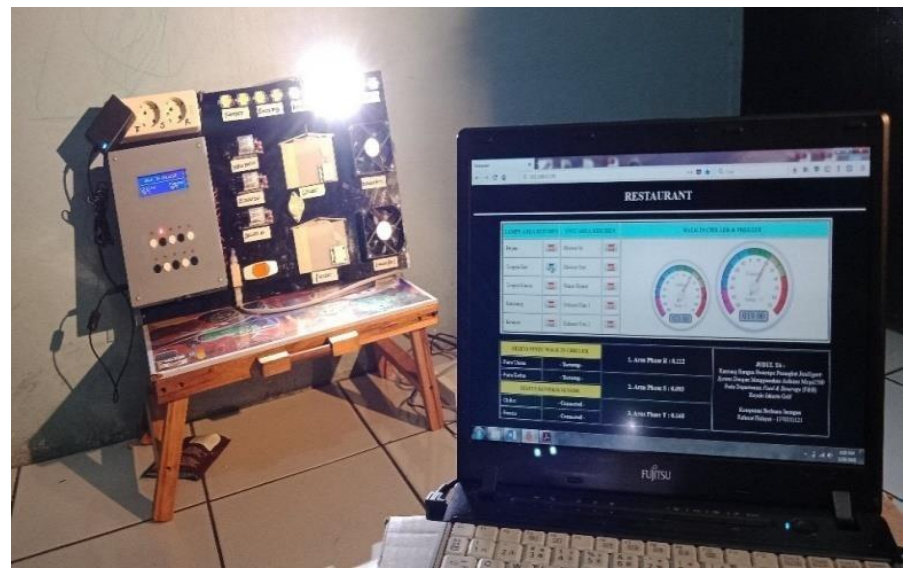

Gambar 11. Pengujian aplikasi

Adapun hasil pengujian dapat dilihat pada tabel 2, tabel 3 , tabel 4 dan table 5 .

Tabel 2. Hasil pengujian development board

\begin{tabular}{lll}
\hline \multicolumn{1}{c}{ Skenario Uji } & \multicolumn{1}{c}{ Hasil yang Diharapkan } & Hasil \\
\hline Pembacaan sensor suhu & Hasil pembacaan sesuai dan tetap stabil & Sesuai \\
Pembacaan sensor listrik & Hasil pembacaan sesuai dan tetap stabil & Sesuai \\
Pembacaan sensor magnet & Hasil pembacaan tetap stabil & Sesuai \\
Pemisahan signal noise & Mampu mengakuisisi data riil & Sesuai \\
\hline
\end{tabular}


Tabel 3. Hasil pengujian kirim dan terima data pada development board

\begin{tabular}{clc}
\hline \multicolumn{1}{c}{ Skenario Uji } & \multicolumn{1}{c}{ Hasil yang Diharapkan } & Hasil \\
\hline Kirim hasil pembacaan sensor & $\begin{array}{l}\text { Server menerima data, dan memberikan } \\
\text { respon "berhasil" }\end{array}$ & Sesuai \\
Request data ke server & $\begin{array}{l}\text { Server menerima data, dan memberikan } \\
\text { respon berupa data yang di request. }\end{array}$ & Sesuai \\
\hline
\end{tabular}

Tabel 4. Hasil pengujian dashboard

\begin{tabular}{clc}
\hline Skenario Uji & \multicolumn{1}{c}{ Hasil yang Diharapkan } & Hasil \\
\hline Visualisasi & $\begin{array}{l}\text { Server menampilkan gauge meter, angka dan } \\
\text { tabel sesuai dengan setelan yang dilakukan }\end{array}$ & Sesuai \\
Update data otomatis & $\begin{array}{l}\text { Server secara berkala memeriksa data } \\
\text { terbaru, jika ada maka gauge meter, angka- } \\
\text { angka dan tabel selanjutnya di-update }\end{array}$ & Sesuai \\
& \\
\hline
\end{tabular}

Tabel 5. Hasil Pengujian IOT

\begin{tabular}{lll}
\hline \multicolumn{1}{c}{ Skenario Uji } & \multicolumn{1}{c}{ Hasil yang Diharapkan } & Hasil \\
\hline $\begin{array}{l}\text { Update data otomatis } \\
\text { Update data pada field chart } \\
\text { channel }\end{array}$ & Data masuk ke server thingspeak. & Sesuai \\
& Data pada channel terpisah berdasarkan & Sesuai \\
& yang di upload pada field chart. & \\
\hline
\end{tabular}

\section{Kesimpulan}

Hasil analisis hingga pengujian yang telah dilakukan mengahasilkan prototipe sistem pengontrolan dan monitoring peralatan dari jarak jauh dapat dioperasikan melalui jaringan internet dengan menggunakan aplikasi web browser. Pengontrolan segala bentuk kerusakan yang disebabkan kelalaian perawatan terhadap peralatan dapat diminimalisir dengan adanya sensor-sensor yang terpasang pada tiap alat. Pengontrolan dan monitoring untuk menghemat energi listrik dari penggunaan yang tidak sesuai telah berfungsi sesuai dengan desain sistem. Pembuatan sistem dilakukan menggunakan sensor suhu termistor, sensor magnet, sensor thermo fuse, dan sensor arus ACS712.

\section{Daftar Pustaka}

[1] A. Rahman. Pengantar Ilmu Perhotelan dan Restoran. Yogyakarta: Graha IImu, 2005

[2] J. Lianda, D. Handarly, Adam, Sistem Monitoring Konsumsi Daya Listrik Jarak Jauh Berbasis Internet of Things. JTERA (Jurnal Teknologi Rekayasa). 2019; 4(1):79-84

[3] Agung Ayu Putri, Gusti, Made Ika Marini Mandenni, Ni, Desain Saklar Otomatis Untuk Kontrol Peralatan Listrik di Bangunan. Jurnal IImiah Merpati (Menara Penelitian Akademika Teknologi Informasi). 2019; 7(1):12-20

[4] T. D. Hendrawati, Y. D. Wicaksono, E. Andika, Internet of Things: Sistem Kontrol Monitoring Daya Perangkat Elektronika, JTERA (Jurnal Teknol. Rekayasa). 2018; 3(2):177-184

[5] Alipudin, Muhammad Asep, Rancang Bangun Alat Monitoring Biaya Listrik Terpakai Berbasis Internet Of Things (IOT), Jurnal Online Mahasiswa (Jom) Bidang Teknik Elektro. 2018;1(1):1-11

[6] Ali Khumaidi, Wargiono. Perancangan Building Management System Menggunakan Arduino Mega 2560 dan Layanan Cloud. Prosiding Seminar Nasional dan Teknologi. Jakarta. 2018; 1: 667-673

[7] Eka Putri, I Gusti Putu Mastawan; Giriantari, Ida Ayu Dwi, Jasa Lie, Monitoring Penggunaan Daya listrik Sebagai Implementasi Internet of Things Berbasis Wireless Sensor Network. Majalah IImiah Teknologi Elektro. 2017; 16(3):50 - 55

[8] N. A. Hidayatullah, D. E. Juliando, Desain dan Aplikasi Internet of Thing (loT) untuk Smart Grid Power Sistem, Jurnal Ilmiah Pendidikan Teknik Elektro. 2017; 2(1):35-44

[9] G. Diori, D. A. Rianjani, G. Maulana, T. Z. Tamzil, M. Manawan, A. Sukandi. Sistem Otomatisasi dan Monitoring Perawatan Berkala AC (Air Conditioner) Berbasis Arduino 
yang Terintegrasi loT (Internet of Things). Prosiding Seminar Nasional Teknik Mesin Politeknik Negeri Jakarta. Jakarta. 2019; 1:184-193

[10] S. Harianto, A. B. Setiawan, Anggraini Puspita Sari, Studi Tentang Penggunaan Metode Scanning pada Sistem Telemetri Pendeteksi Kerusakan Air Conditioner Kendaraan, Jurnal Elektrika Teknik Elektro. 2017; 1(1): 47-51

[11] Son Ali Akbar, Dimas Baskoro Kalbuadi, Anton Yudhana, Online Monitoring Kualitas Air Waduk Berbasis Thingspeak, Jurnal Transmisi. 2019; 21(4): 109-115

[12] Pasha, Sharmad, Thingspeak Based Sensing and Monitoring System for loT with Matlab Analysis. International Journal of New Technology and Research. 2016; 2(6): 19-23 